\title{
XII. Observations on the effects which take place from the destruction of the membrana tympani of the ear
}

\section{Mr. Astley Cooper \& Everard Home Esq. F.R.S.}

To cite this article: Mr. Astley Cooper \& Everard Home Esq. F.R.S. (1801) XII. Observations on the effects which take place from the destruction of the membrana tympani of the ear , Philosophical Magazine Series 1, 8:32, 359-366, DOI: 10.1080/14786440108562657

To link to this article: http://dx.doi.org/10.1080/14786440108562657

曲 Published online: 25 Jan 2010.

Submit your article to this journal $\pi$

Џll Article views: 2

Q View related articles $\sqsubset$ 
place foon after, he proceeded back again to $Y$ andoka, and Buhahara the capital, where he was detained for a fhort time as a flave; but having repaired fome of the king's weapons he obtained his liberty, and travelled in the fuite of the king to Kahoratho.

[To be continued.]

XII. Obfervations on the Effects wbicb take place from the Defruction of the Membrana Tympani of the Ear. By $M r$. Astley Cooper. In a Letler to Everard Hом E, Efq. F.R.S. by avbom fome Remarks are added*. DEAR SIR,

A $\mathrm{T}$ the time you were engaged in the inveftigation of the Aructure and ufes of the membrana tympani, you mentioned a wifh to afcertain the effect a rupture of that membrane would have upon hearing. I now fend you fome obfervations on that fubject, which, if you think them of fufficient importance, you will do me the honour of prefenting to the Royal Society. I am, \&c.

ASTLEY COOPER.

Anatomists have endeavoured to afcertain, by experiments on quadrupeds, the lofs of power which the organ of hearing would fuftain by perforating the membrana tympani; dogs have been made the fubject of thefe trials; but the refults have been neither clear nor fatisfactory, and they accord but little with the phænomena I am about to relate.

Mr. Chefelden had conceived the defign of making the human organ itfelf the fubject of direct experiment; and a condemned criminal was pardoned, on condition of his fubmitting to it; but a popular outcry being raifed, it was thought proper to relinquith the idea.

Though denied the aid of experiment, we are not withont the means of obtaining knowledge upon fuch fubjects; fince the changes produced by difeafe frequently furnith a clue which is equally fatisfactory.

It often happens, that fome parts of an organ are deftroyed

* From the Tranfactions of the Royal Society for 1800 . 
by difeafe, whilf others are left in their natural ftate; and hence, by the powers retained by fuch organ, after a partial deftruction, we are enabled to judge of the functions performed by thofe parts when the whole was in health.

Guided by this principle, I have made the human ear the fubject of obfervation, and have endeavoured to afcertain the degree of lofs it futtains in its powers by the want of the membrana tympani; a membrane which has been generally confidered, from its fituation in the meatus, and its connection with the adjacent parts by a beautiful and delicate ftructure, as effentially neceffary to the fenfe of hearing; but which, as appears by the following obfervations, may be lost, with little prejudice to the functions of the organ.

Mr. P—, a medical fudent at St. Thomas's hofpital, of the age of twenty years, applied to me, in the winter of 1797, while he was attending a courfe of anatomical lectures, requefting my opinion upon the nature of a complaint in his ear, which had long rendered him nightly deaf.

Upon inquiring into the nature of the fymptoms which had preceded, and of thofe which now accompanied the difeafe, he informed me, that he had been fubject from his infancy to pains in the head, and was attacked, at the age of ten years, with an inflammation and fuppuration in the left ear, which continued difcharging matter for feveral weeks : in the fpace of about twelve months after the firft attack, fymptoms of a fimilar kind took place in the right ear, from which alfo matter iffued for a confiderable time. The difcharge in each inftance was thin, and extremely offenfive to the fmell; and, in the matter, bones or pieces of bones were obfervable. The immediate confequence of thefe attacks was a total deafnefs, which continued for three months; the hearing then began to return, and, in about ten months from the laft attack, was reftored to the ftate in which it at prefent remains.

Having thus defcribed the difeafe and its fymptoms, he gave me the following fatisfactory proof of each membrana tympani being imperfect. Having filled his mouth with air, he clofed the noftrils and contracted his cheeks : the air, thus compreffed, was heard to rufh through the meatus au- 
Aitorius with a whitling noife, and the hair hanging from the temples became agitated by the current of air which iffued from the ear. To determine this with greater precifion, I called for a lighted candle, which was applied in turn to each ear, and the flame was agitated in a fimilar manner. Struck with the novelty of thefe phænomena, I withed to have many witneffes of them, and therefore requefted him, at the conclufion of the lecture upon the organ of hearing, to exhibit them to his fellow ftudents; with which requeft he was fo obliging as to comply.

It was evident from thefe experiments, that the membrana tympani of each ear was incomplete, and that the air iffued from the mouth, by the Euftachian tube, through an opening in that membrane, and efcaped by the external meatus.

To determine the degree in which the membrana tympani had been injured, I paffed a probe into each ear, and found that the membrane on the left fide was entirely deftroyed; fince the probe ftruck againft the petrous portion of the temporal bone, at the interior part of the tympanum, not by paffing through a fmall opening; for, after an attentive examination, the fpace ufually occupied by the membrana tympani was found to be an aperture, without one trace of membrane remaining.

On the right fide, alfo, a probe could be paffed into the cavity of the tympanum; but here, by conducting it along the fides of the meatus, fome remains of the circumference of the membrane could be difcovered, with a circular opening in its centre, about the fourth of an inch in diameter.

From fuch a deftruction of this membrane, partial indeed in one ear, but complete in the other, it might be expected that a total annihilation of the powers of the organ would have followed: but the deafnefs was inconfiderable. This gentleman, if his attention were exerted, was capable, when in company, of hearing whatever was faid in the ufual tone of converfation; and it is worthy of remark, that he could hear with the left ear better than with the right, though in the left no traces of the membrana tympani could be perceived.

When attending the anatomical lectures, alfo, he could 
hear, even at the moft diftant part of the theatre, every word that was delivered; though, to avoid the regular and conftant exertion which it required, he preferred placing himfelf near the lecturer.

I found, however, that when a note was ftuck upon the piano forte, he could hear it only at two-thirds of the diftance at which I could hear it myfelf; and he informed me, that in a voyage he had made to the Faft Indies, while others, when hips were hailed at fea, could catch words with accuracy, his organ of hearing received only an indiftinct impreffion. But the moft extraordinary circumfance in Mr. P__'s cafe is, that the ear was nicely fufceptible of mufical tones; for be played avell on the fute, and bad frequently borne a part in a concert. I fpeak this, not from his own authority only, but alfo from that of his father, who is an excellent judge of mufic, and plays well on the violin: he told me, that his fon, befides playing on the flute, fung with much tafte, and perfectly in tune.

The night degree of deafnefs of which $\mathrm{Mr}_{3} \mathrm{P}$. complained, was always greatly increafed by his catching cold : an effect which feems to have arifen from the meatus being clofed by an accumulation of the natural fecretion of the ear; for it frequently happened to him, after he had been fome time deaf from cold, that a large piece of hardened wax, during a fit of coughing, was forced from the ear, by the air rufhing from the mouth through the Euftachian tube, and his hearing was inftantly reftored.

From bathing, likewife, he fuffered confiderable inconvenience, unlefs his ears were guarded againft the water, by cotton being previoully forced into the meatus. When this precaution was neglected, the water, as he plunged in, by rufhing into the interior parts of the ears, occafioned violent pain, and brought on a deafnefs, which continued until the caufe was removed, that is, until the water was difcharged; but he had acquired the habit of removing it, by forcing air from the mouth through the ear.

In a healthy ear, when the meatus auditorius is ftopped by the finger, or is otherwife clofed, a noife fimilar to that of a diftant roaring of the fea is produced: this arifes from 
the air in the meatus being compreffed upon the membrana tympani. In the cafe here defcribed, no fuch fenfation was produced: for, in Mr. P.'s ear, the air, meeting with no impediment, could fuffer no compreffion; fince it found a paffage, through the open membrane, to the mouth, by means of the Euftachian tube.

$\mathrm{Mr}$. P. was liable to the fenfation commonly called the tectb being on edge, in the fame degree as it exifts in others; and it was produced by fimilar acute founds, as by the filing of a faw, the rubbing of filk, \&c. Its occurring in him feems to difprove the idea which has been entertained of its caufe; for it has been thought, that the clofe connection of the nerve called the corda tympani with the membrana tym pani, expofed it to be affected by the motions of the malleus; and that, as it paffes to nerves connected with the teeth, they would fuffer from the vibratory ftate of the nerve, produced by the agitations of the membrane. But, in this cafe, as the membrane was entircly deftroyed on that fide on which the fenfation was produced, fome other explanation mult be reforted to; and I fee no reafon why this effect fhould not be referred to that part of the auditory nerve which lines the labyrinth of the ear, which, being impreffed by acute and difagreeable founds, would convey the impreffion to the portio dura of the fame nerve, and to the teeth with which that nerve is connected.

The external ear, though two diftinct mufcles are inferted into it, is capable, in its natural ftate, of little motion: however, when an organ becomes imperfect, every ageiat which can be employed to increafe its powers is called into action; and, in the cafe here deferibed, the external ear had acquired a diftinct motion upward and backward, which was obfervable whenever Mr. P. liftened to any thing which he did not diftinctly hear. This power over the mufcles was fo great, that when defired to raife the ear, or to draw it backwards, he was capable of moving it in either direction.

This cafe is not the only one of this defcription which has come under my obfervation; for another gentleman, Mr. A., applied to me under a fimilar complaint, (but in one ear only,) proceeding from fuppuration, and producing the fame effects. 
effects. This gentleman has the fame power of forcing air through the imperfect ear; fuffers equally from bathing, if the meatus auditorius be unprotected; and feels, even from expofure to a ftream of cold air, very confiderable pain. The only difference I could obferve was, that in Mr. A.'s cafe; the defect of hearing in the difeafed organ was fomewhat greater than in the former; for thougli, when his found ear was clofed, he could hear what was faid in a common tone of voice, yet he could not diftinguifh the notes of a piano forte at the fame diftance : a difference which might have in part arifen from the confufed noife which is al ways produced by clofing the found ear; or becaufe, as he heard well on one fide, the imperfect ear had remained unemployed, and confequently had been enfeebled by difufe.

From thefe obfervations it feems evidently to follow, that the lofs of the membrana tympani in both ears, far from producing total deafnefs, occafions only a night diminution of the powers of hearing.

Anatomifs who have deftroyed this membrane in dogs have afferted, that at firt the effect on the fenfe of hearing was trivial; but that, after the lapfe of a few months, a total deafnefs enfued. Baron Haller alfo has faid, that if the membrane of the tympanum be broken, the perfon becomes at firt hard of hearing, and afterwards perfectly deaf. But, in thefe inftances, the deftuction muft have extended further than the membrana tympani; and the labyrinth muft have fuffered from the removal of the ftapes, and from the confequent difcharge of water contained in the cavities of the internal ear; for it has been very conftantly obferved, that when all the fmall bones of the ear have been difcharged, a total deafnefs has enfued.

It is probable, that in inftances in which the membrana tympani is deftroyed, the functions of this membrane have been carried on by the membranes of the feneftra ovalis and feneftra rotunda: for, as they are placed over the water of the labyrinth, they will, when agitated by the impreffions of found, convey their vibrations to that fluid in a frmilar manner, though in fomewhat an inferior degree, to thofe which are conveyed by means of the membrana tympani and the fmall 
Imall bones which are attached to it; and thus, in the organ of hearing, each part is admirably adapted, not only to the purpofe for which it is defigned, but alfo as a provifion againft accident or difeafe; fo that, whenever any particular' part is deftroyed, another is fubftituted for it, and the organ, from this deprivation, fuffers but little injury in its functions.

It feems that the principal ufe of the membrana tympani is, to modify the impreffions of found, and to proportion then to the powers and expectation of the organ. Mr. P. had loft this power for a confiderable period after the deftruction of the membrane; but, in procefs of time, as the external ear acquired the additional motions I have defcribed, founds were rendered ftronger or weaker by them. When; therefore, he was addreffed in a whifper, the ear was feen immediately to move; but, when the tone of voice was louder, it then remained altogether motionlers.

Some additional Remarks, on the Mode of Hearing in Cajes where tbe Membrana Tympani bás been deftroyed. By Everard Home, Efq.

After having communicated to this learned Society the very curious facts contained in Mr. Cooper's paper, which prove that the organ of hearing is capable of receiving all the different impreffions of found, when the membrana tympani has been deftroyed, it may not be improper to explain; from the obfervations contained in a former paper on this fubjest, in what manner this may take place.

It is there ftated, that any vibrations communicated directly to the bones of the fkull, are as accurately impreffed upon the organ, as through the inedium of the membrana tympani. The office of that membrane is therefore to afford an extended furface, capable of receiving impreffions from the external air, and of communicating them to the fmall bones of the ear; which a membrane would be incapable of doing, unlefs it had a power of varying its tenfion, to adapt it to different vibrations.

In the above cafes, in which this membrane, the malleus, and the incus, had been deftroyed, it would appear that the ftapes was aced upon by the air received into the cavity of Vos. VIII.

$3 \mathrm{~B}$

the 
the tympanum, and communicated the impreffions immediately to the internal organ. This not happening for fome months after the membrane was deftroyed, probably arofe from the inflammation of the tympanum confining the ftapes, and rendering its vibrations imperfect.

That founds can be communicated with accuracy by the bones of the $\mathrm{k}$ kull to the internal organ, when received from folid or liquid fubftances, has long been well underftood.

That the membrana tympani is incapable of perfectly anfwering this purpofe, when founds are propagated through air, has been a generally received opinion; to refute which, was the object of my former paper. That, in cafes in which the membrana tympani has been deftroyed, the air is capable of acting with fufficient force upon the ftapes to communicate vibrations to it, and to produce on the internal organ the neceffary effect for perfect hearing, is completely afcertained by Mr. Cooper's obfervations.

XIII. Analy/ss of a Stone called the Gadolinite; witb an Account of fome of the Properties of the nequ Eartb it contains. By C. VAugueliN*.

$\mathrm{T}$

$\mathrm{HE}$ number of fimple bodies, and particularly that of carths, has been greatly increafed within a few years paft; and if chemiftry go on ftill thus advancing, it is to be apprehended that the time may arrive when the human mind will not be able to embrace all the combinations produced by the nultitude of fimple bodies.

But the analogy which exilts between certain claffes of natural fubitances, gives clucmifts reafon to fufpect that they contain a common generating principle, and affords them a hope that fome fortunate chance, or an experiment made by fome man of genius, will reduce them all to one fingle kind, either by difengaging them from thofe principles which eftablifh differences between them, or by combining thefe fame elements to thofe which are fimple.

* From the Annales de Cbimie, No. 107. 